\title{
Accounting
}

\section{The economic growth and affecting factors in Sumatera island}

\section{Yolanda $^{a^{*}}$, Patria Nagara ${ }^{\mathrm{b}}$, Sumarni ${ }^{\mathrm{a}}$ and Efiani ${ }^{\mathrm{c}}$}

${ }^{a}$ University Borobudur Jakarta, Indonesia

${ }^{b}$ STIE Sumbar Pariaman, Sumatera Barat, Indonesia

'University Azzahra Jakarta, Indonesia

\begin{tabular}{l} 
C H R O N I C L E \\
\hline Article history: \\
Received: October 27,2020 \\
Received in revised format: \\
November 262020 \\
Accepted: December 9, 2020 \\
Available online: \\
December 9, 2020 \\
\hline Keywords: \\
Education \\
Economic openness \\
Road infrastructure \\
Investment \\
Poverty \\
Unemployment \\
Economic Growth \\
OLS method
\end{tabular}

\begin{abstract}
A B S T R A C T
The indicators of success in macro development can be measured from the economic growth, which is reflected in changes in the Gross Regional Domestic Product (GRDP). The factors which affect the economic growth are very complex. This study analyzes the economic growth and the factors that affect Sumatra island. The data used is panel data with descriptive analysis techniques and multiple linear regression. Based on the research results: Education, economic openness, road infrastructure, and investment have a positive and significant effect on economic growth and poverty and unemployment have a negative and significant effect on economic growth. Besides, the results of panel data explained that the openness of the economy to economic growth is very low, while the highest is education.
\end{abstract}

\section{Introduction}

The important indicators in economic development can be indicated from the rate of economic growth, where the economic growth is defined as the increasing per capita output within a certain period of time, Meanwhile, Sukirno (2011) stated that the development of activities in the economy has caused the increasing of goods and services produced in society. The economic growth of a country may reflect the welfare of the population of the country or it can also be an indicator of a country's ranking.

The measurement of the economic growth indicator is the growth rate of Gross Regional Domestic Product (GRDP). The use of GRDP growth as a measurement of economic growth is caused by (1) GRDP is the result of the additional value of all production activities in the economy, (2) PDRB calculations include the value of products produced in a certain period, and (3) PDRB calculations, the border is the State (domestic economy). The economic growth is reflected in changes in Gross Regional Domestic Product (GRDP) in a region, according to Todaro and Smith (2008), the rate of GDP growth at constant prices. Sumatera island is an island that is in the Western Region of Indonesia which consists of 10 provinces, namely Nanggroe Aceh Darussalam (NAD), North Sumatra, South Sumatra, Bangka Belitung, West Sumatra, Riau, Riau Islands, Jambi, Lampung, and Bengkulu. The economic growth rate of 10 (ten) Provinces in Sumatra Island during 2014 - 2018 is shown in Fig. 1 below:

* Corresponding author.

E-mail address: yolanda@borobudur.ac.id (Yolanda) 


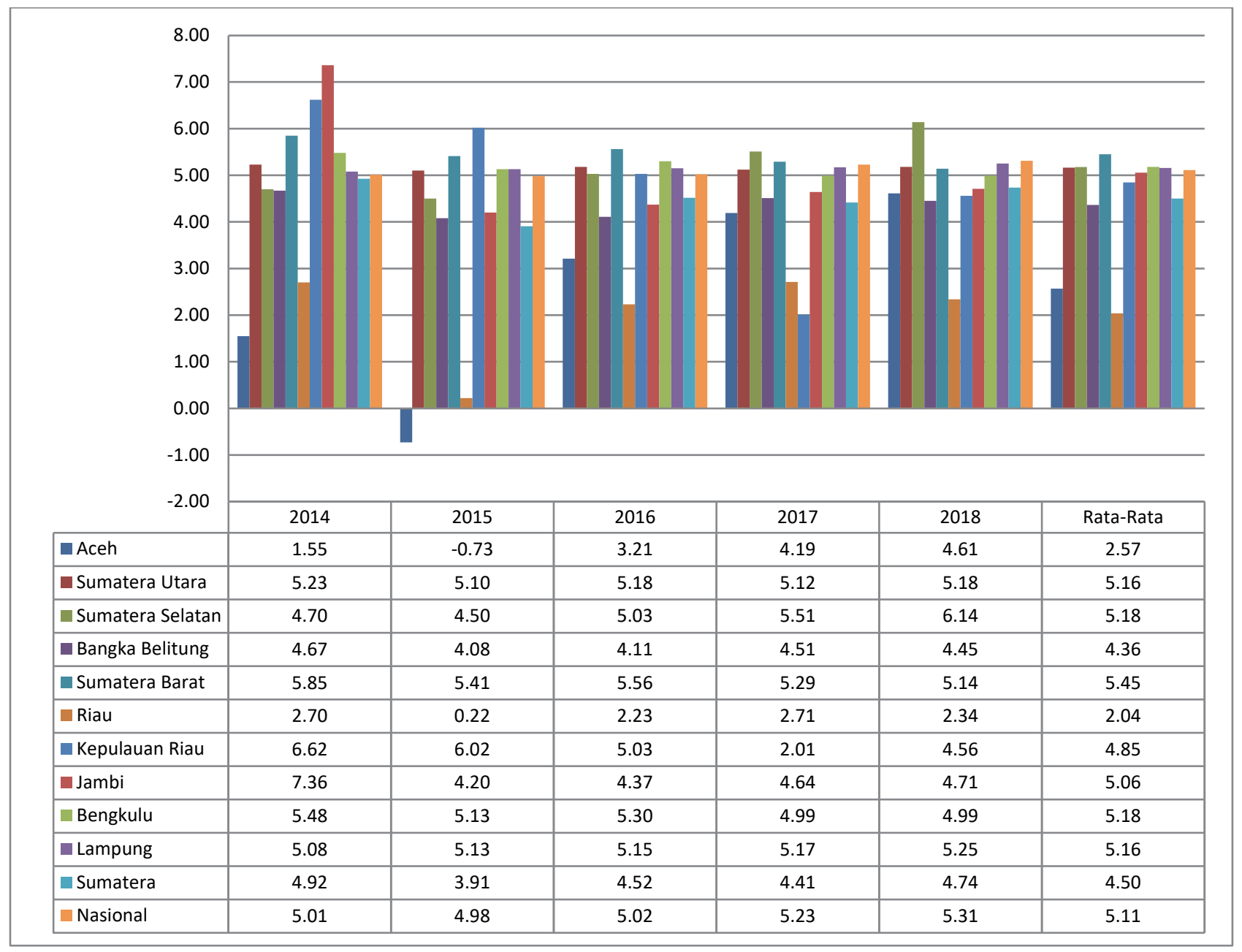

Source: Statistics Indonesia (2019)

Fig. 1. The Economic Growth Rate of 10 Provinces on the Island of Sumatra for the 2014 - 2018 Period

As a whole, the economic growth in ten (10) provinces on the island of Sumatra showed a fluctuating trend. During the last 5 years (2014 - 2018), the highest economic growth rate was in West Sumatra Province with an average value is 5.45 percent. Meanwhile, the lowest economic growth was in Riau Province is $2.04 \%$. The average growth rate of 10 (ten) provinces $(4.5 \%)$ is still lower than the national economic growth average is $5.11 \%$. To increasing of the economic growth of a country can be driven by; the availability of human resources quality (HR), economic openness, infrastructure, investment, poverty, and unemployment and so on. Quality resources can be measured from the level of education, where the level of education can be seen from the Literacy Rate. The Literacy Rate is the proportion of the population aged of 15 years and over who has the ability to read and write letters and other letters. The average of the Literacy Rate for the island of Sumatra (98.16) is higher than the National Literacy Rate (95.36). The lowest average of the Literacy Rate province is Lampung Province (96.76), while the highest average of the Literacy Rate is Riau province. The openness of foreign trade shows that trade barriers between countries is declining and the share of trade is increasing. The condition of the economic openness in Indonesia in 2018 was 50.4 and this indicates that the level of economic openness is still low. For the island of Sumatra, the level of openness is 45.9 and lower than Indonesia level in 2018. The market share of Indonesian products, especially the island of Sumatra, is still very low. Geographically, the island of Sumatra is located $6^{\circ} \mathrm{N}-6^{\circ} \mathrm{S}$ and in the north, it is bordered by Bay of Benggala, in the east of Strait of Malacca, in the south of Sunda Strait and in the west of Indian Ocean with an area of 473,481 km2. The length of roads in 2019 on the island of Sumatra is $183,434 \mathrm{~km}$, while in 2018 it is $184,860 \mathrm{~km}$ with a growth of $-0.8 \%$, this does not include toll roads. This means that the decline of growth is caused the existing roads were renovated to be toll roads. In 2017, the length of the road was $184,741 \mathrm{~km}$ with a growth of $0.06 \%$. The growth of road infrastructure on Sumetera Island is still slow. The investment referred in this case is Gross Fixed Capital Formation. Gross Fixed Capital Formation for the island of Sumatra is smaller than the National Gross Fixed Capital Formation for 2014-2018, this can be seen from the average growth of Gross Fixed Capital Formation, in national scale is 5.6\% and the island of Sumatra is $4.1 \%$. Bangka Belitung Province is a province that has the highest average Gross Fixed Capital Formation, which is 5.8\%, while Jambi province has the lowest average Gross Fixed Capital Formation during the 2014-2018 periods. 
The poverty is multidimensional; this is due to many aspects which affect it. For 5 years (2014 - 2018) the average growth of the number of poor people on Sumatra island has decreased by -0.6. This number is lower than the decline of poor people growth in national scale. The development of the unemployment rate can be measured using the Open Unemployment Rate and the data can be used to monitor and evaluate the development of the unemployment rate. During 2014 - 2018, the average of Open Unemployment Rate on Sumatra island was still below the national Open Unemployment Rate which is 5.53\% and 5.71\%. This suggests that the average National Open Unemployment Rate is higher than the Open Unemployment Rate on Sumatra island. Based on the descriptions above, this study aims to examine the factors that affect the economic growth on Sumatra Island through the conditions of the level of education, economic openness, road infrastructure, investment, poverty, and unemployment levels and how they influence it simultaneously and partially.

\section{Literature Review}

The Economic growth is the activities development in economy that causes goods and services are produced to increase the prosperity of the community. According to Kuznet (Jhigan, 2014) economic growth is the long-term of the increasing in a country's ability to provide its citizens with a wide variety of economic goods. The rate of economic growth can be calculated directly from the available real national income data, with the formula:

$g=\frac{\text { PNriil }_{1}-\text { PNriil }_{0}}{\text { PNriil }_{0}} \times 100$,

where:

$$
\begin{aligned}
& \mathrm{g} \quad=\text { the rate of economic growth, } \\
& \mathrm{PN}-\text { riil }_{1}=\text { national income for next year, } \\
& \mathrm{PN}-\text { riil }_{0}=\text { national income in previous year. }
\end{aligned}
$$

Education is regulated in Government Regulation Number 47 of 2008 concerning Compulsory Education. The measurement level and quality of education in an area is from the number of the literacy rate. Literacy is the ability to read and write, while the literacy rate is the proportion of the population aged 15 years and over who has the ability to read and write letters and other letters without having to understand what they read / write. The formula for calculating the literacy number is as follows:

$$
\text { Literacy Rate }=\frac{\mathrm{a}}{\mathrm{b}} \times 100
$$

Information:

$\mathrm{a}=\quad$ total of population aged 15 years and over who can read and write.

$\mathrm{b}=\quad$ total of residents aged 15 years and over

According to Thirlwall (2006), international trade contributes to a more efficient allocation of resources and affects economic growth from one country to another. While Berg (2005) stated that international trade provides an opportunity for each country to specialize (produce goods) and earn higher income and accelerate the economic growth of a country. Thus Barro, 2003 stated that openness to international trade is one of the fundamental factors in increasing long-term economic growth. Nowbutsing (2014) classified the level of openness into 3 categories, there are less than $50 \%$ included in the low level of openness category, more than $50 \%$ and less than $100 \%$ included in the medium level of openness category and more than $100 \%$ included in the high level of openness category. Moteff et al. (2003) defined that infrastructure from the viewpoint of economy, defense, and government sustainability and NSS et al. (2004) stated that infrastructure could increase household production and consumption, while American Public Works Association (Stone, 1974 In Kodoatie, 2005), stated that infrastructure was physical facilities that were developed or needed by public agencies for government functions. Next NSS et al. (2015), stated that infrastructure includes roads, bridges, water and sewage systems, airports, ports, public buildings, and also includes schools, health facilities, prisons, recreation, power plants, security, fires, landfills, and telecommunications and men according to Sjafrizal (2012) the government had the responsibility for the provision of these infrastructure facilities. The availability of this infrastructure can increase efficiency and productivity in carrying out social and economic activities.

The term investment is often referred to as investor or capital formation and investment can be defined as a company expenditure or investment to buy capital goods and production equipment to increase the ability to produce goods and services available in the economy (Sukirno, 2000). Thus, investment can be said to be one of the determinants of the rate economic growth. This can be seen from the Keynes theory about national income which is influenced by public consumption, investment, government spending, and the difference between exports and imports. Types of investment that can affect the rate of economic growth can be real investment (tangible investment) and financial investment, while other types are direct and investment portfolio. Investment is one of the main factors driving the economic growth of a region. Thus theoretically, the rate of economic growth has a positive correlation with investment as stated, among others Keynes in Jhingan (2003) and Mankiw (2006), Harrod Domar in Arsyad 
(2010), Solow-Swan in Arsyad (2010), Kuznet in Arsyad (2010), Todaro (2000), and Schumpeter in Sukirno (2008). According to Aurangzeb (2012), investment consists of public investment, private investment, and foreign direct investment have a positive and significant effect on economic growth in Pakistan. Next Chidoko and Sachirarwe (2015) and Manamba and Massawe (2016) also found evidence that investment affects economic growth. The condition of a person's economic inability to meet the average standard of living of the people in an area is called poor or inability of income to meet average living standards such as public health and education in Law no. 24 of 2004. According to the Human Development Index (HDI) the measurement of poverty, among others; life expectancy, education / literacy rates, and purchasing power parity. Meanwhile, other indicators can also be Head Count Index, Poverty Gap Index, and Square Poverty Index.

According to the classical theory, unemployment occurs due to misallocation of resources and according to keyless theory unemployment occurs due to low aggregate demand, while according to the Central Statistics Agency unemployment is a population who is not working but is looking for working. Thus, the three definitions above explain the existence of resources that are not used / wasted. The result of unemployment (Sukirno, 2000) is that the community's prosperity is not maximum, government tax revenue is reduced, and economic growth is low / decline as a result of low interest in investment by the community.

\subsection{Hypothesis}

Based on the description above, the research hypothesis can be formulated as follows:

- The level of education, economic openness, road infrastructure, investment, poverty, and unemployment affect on economic growthsimultaneously.

- Education level affectson economic growthpartially.

- Economic openness affectson economic growthpartially.

- Road infrastructure affectson economic growthpartially.

- Investment affectson economic growthpartially.

- $\quad$ Poverty affectson economic growthpartially.

- Unemployment affectson economic growthpartiall.

Referring to the above hypothesis, role education level, economic openness, road infrastructure, investment, poverty, and unemployment to economic growth in brief can be illustrated in the following figure:

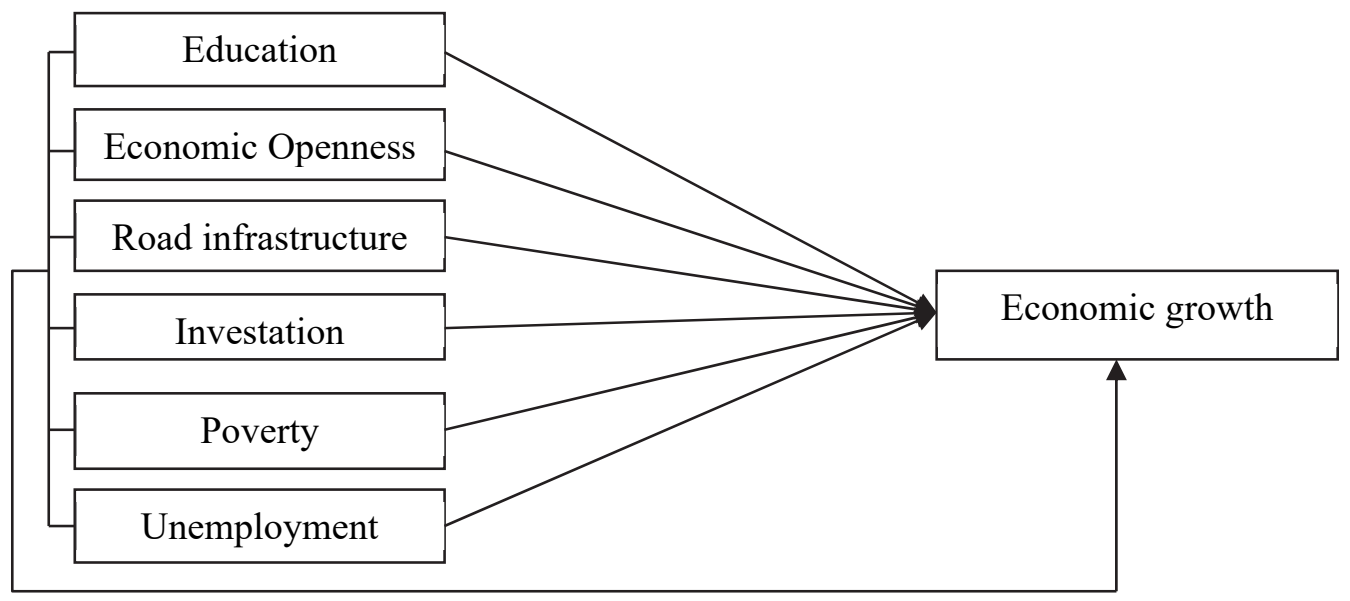

Fig. 2. Framework

Source : Data Processed, 2020

\section{Methodology}

This study examines the factors that affect economic growth, by examining the effect of education levels, economic openness, road infrastructure, investment, poverty, and unemployment levels. The approach used to measure the effect among variables is a quantitative approach. 
The estimation of the equation model used panel analysis techniques, where panel data is a combination of Time Series and Cross Section data. Panel data regression estimation techniques are Common Effect Model, Fixed Effect Model, and Random Effect Model and to determine and select the right model from the three panel data regression estimation models, Chow and Hausman testing is required. The approach used for the choice of the above model is if the common effect and fixed effect models used the Ordinary Least Squared (OLS) approach while the random effect used the Generalized Least Squares (GLS). The data used must perform a classical assumption test (normality test, heteroscedasticity test, multicollinearity test, and autocorrelation test), so that the model formed meets the BLUE (Best Linear Unbias Estimator) requirements.

After the model meets the BLUE (Best Linear Unbias Estimator) requirements, then the F test (simultaneous) and $t$ test (partial) are performed. Linear Multiple Regression Equation (Linear Multiple Regression) is as follows:

$$
Y=\beta_{0}+\beta_{1} X_{1}+\beta_{2} X_{2}+\beta_{3} X_{3}+\beta_{4} X_{4}+\beta_{5} X_{5}+\beta_{6} X_{6}+\text { et }
$$

Where:

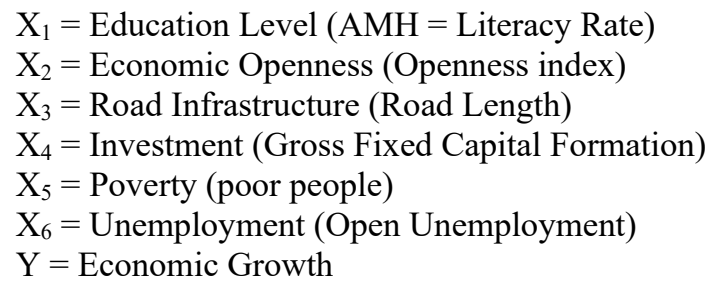

To measure the ability of the model formed in explaining the variation in the independent variable, the coefficient of determination is used which indicates that it meets the characteristics set out in an econometric model (the goodness of an econometric model).

\section{Results and Discussion}

This study used panel data estimation and the selected model after the Chow test and Hausman test is the Fixed Effect model.

Table 1

Fixed Effect Model Results

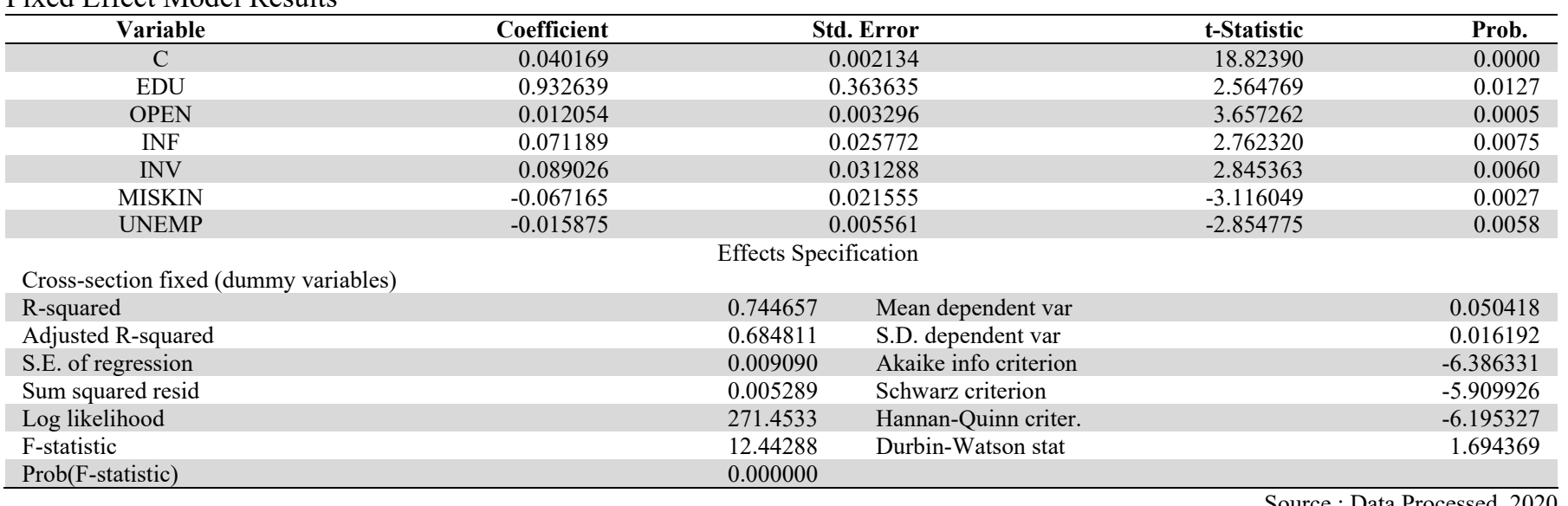

The result of the $\mathrm{F}$ test in this study indicates that the independent variables (education level, economic openness, road infrastructure, investment, poverty, and unemployment) simultaneously or collectively have a significant effect on economic growth. While the partial test $(\mathrm{t})$ is

a. Education (Literacy Rate) has a positive and significant effect on economic growth In Sumatra Island. The effect of education on economic growth is strengthened by previous research among others: Ali and Jabeen (2015), Odit et al. (2010), Kobzev Kotásková et al. (2018), Hanif and Arshed (2016) and Leasiwal (2013).

b. Economic Openness and Economic Growth in Sumatra Island have a positive and significant effect. The results of this study are supported by previousresearchamong others: Lloyd and MacLaren (2002), Chang and Mendy (2012) and Nowbutsing (2014), while Sheng et al. (2019) showed different (negative) results. Meanwhile, Ndulu, Kritzinger-van and Reinikka (2005) in their research results, one of the keys to hampering rapid economic growth is insufficient infrastructure. 
c. Road Infrastructure has a positive and significant effecton Economic Growth. The results of this study are in line with the previousresearchamong others: CP Ng et al (2010) who declared to have a significant effect. And Maryaningsih et al. (2014), stated that the availability of basic infrastructure is needed to achieve high and sustainable growth.

d. Investment has a positive and significant effecton economic growth. The results of this study are in line with the previous research among others: Aurangzeb (2012), Chidoko and Sachirarwe (2015) and Epaphra and Massawe (2016) in his research found the same results that investment has a positive and significant effecton economic growth. While Bambang Sucipto et. Al (2018) resulted that Investment does not have a positive and significant effecton economic growth.

e. Poverty has a negative and significant effect on economic growth in Sumatra island, while Nindi, Odhiambo (2015) found different evidence that there is no effect of poverty on economic growth both in the short and long term and research results from Haifa and Mabrouka (2016) that poverty has a negative and significant effect on economic growth for Tunisia.

f. Unemployment does not have a positive and significant effectonEconomic Growth. This is in line with previousesearch, among others: Kukaj (2018), Akeju and Olanipekun (2014 and Mohseni and Jouzaryan (2016). Meanwhile Kalsum (2017) and Makaringe \& Hlalefang (2018), stated a positive / unidirectional relationship.

The coefficient of determination (KD) for the regression model for the level of education, economic openness, road infrastructure, investment, poverty, and unemployment for economic growth is $68.48 \%$ for economic growth, while $31.52 \%$ is influenced by other variables not included in this research model. The regression model to be formed must be BLUE (Best Linear Un] Estimation), this is so that the regression model created is valid as a forecasting tool. To state that a regression model is valid as a predictor, a Classical Assumption test is performed. According to the Classical Assumption Test, the data used has met the requirements (free from multicollinearity, autocorrelation, and normally distributed data).

In addition, the equation model that is formed must go through the theory suitability test with econometric model (the goodness of an econometric model) and the result is:

\section{a. Theoretical Plausibility}

The model resulting from the relationship between post-estimation variables describes the test results in accordance with the expectations of economic theory.

b. Accuracy of the estimates of the parameter

This research model produces a regression coefficient estimator that is accurate or unbiased and significant both simultaneously and partially.

c. Forecasting ability

The predictive ability rates for both models were over $50 \%$.

d. Explanatory ability

The results of the ability test show that almost all research variables, the SE (standard error) is smaller than $1 / 2$ the regression coefficient, only the Inflation variable has the SE (standard error) value greater than $1 / 2$ the regression coefficient. However, the value is not so far from the value of $1 / 2$ regression coefficient. This means that each variable has a high ability to explain the relationship among the variables studied.

In this case, it can be concluded that the equation model formed has passed the theory suitability test. Based on the classical assumption test and theory suitability test, the equation model is

$\mathrm{Y}=0.0402+0.933(\mathrm{X} 1)+0.012(\mathrm{X} 2)+0.071(\mathrm{X} 3)+0.089(\mathrm{X} 4)-0.0672(\mathrm{X} 5)-0.0158(\mathrm{X} 6)$

\section{Based on}

a. The regression coefficient for the $\mathrm{X}_{1}$ variable is 0.933 , which means that every 1 unit increase in $\mathrm{X}_{1}$ will increase $\mathrm{Y}$ (economic growth) by 0.933 units, while it is assumed that other variables do not change.

b. The regression coefficient of the $\mathrm{X}_{2}$ variable (open economy) is 0.012 , which means that every 1 unit increase in $\mathrm{X}_{2}$ will increase $\mathrm{Y}$ (economic growth) by 0.012 units, it is assumed that other variables do not change.

c. The regression coefficient for the $\mathrm{X}_{3}$ variable (infrastructure) is 0.071 , meaning that every 1 unitincrease in $\mathrm{X}_{3}$ will increase $\mathrm{Y}$ (economic growth) by 0.071 units, it is assumed that other variables do not change.

d. The regression coefficient for the $\mathrm{X}_{4}$ variable (investment) is 0.089 , which means that every 1 unit increase in $\mathrm{X}_{4}$ will increase $\mathrm{Y}$ (economic growth) by 0.089 units, it is assumed that other variables do not change.

e. The regression coefficient for the $\mathrm{X}_{5}$ variable (poverty) is -0.067 , meaning that every 1 unit increase in $\mathrm{X}_{5}$ will reduce $\mathrm{Y}$ (economic growth) by 0.992 units, it is assumed that other variables do not change.

f. The regression coefficient for the $\mathrm{X}_{6}$ variable (unemployment) is -0.016 , which means that every 1 unit increase in $\mathrm{X}_{6}$ will decrease $\mathrm{Y}$ (economic growth) by 0.016 unitsit is assumed that other variables do not change. 
Based on the above, it can be seen that the change in the $\mathrm{X}_{1}$ variable (education) has a big impact on economic growth, where the relationship that occurs is positive / unidirectional. While the smallest effect in this study is economic openness in influencing economic growth.

\section{Conclusion}

Based on the description above, economic growth can be influenced by variables of education, economic openness, infrastructure (length of road), investment (Gross Fixed Capital Formation), simultaneous and partial poverty and unemployment.

Education is a large variable affecting the level of economic growth in this study. It means that the provision of human resources must be the main concern. The available human resources must master in science and technology directly or indirectly and mastery in science and technology certainly requires a large investment in education, so that it can be known the extent to which the inhabitants of an area are open to knowledge.

The openness of the economy has little effect and significant on economic growth. This suggests that export and import activities make a very small contribution to the Gross Regional Domestic Product. This explains that the contribution of economic openness to economic growth is still low and for that, it is necessary to pay attention to the factors that affect the increase in exports and decrease in imports. According to Yolanda (2017) the biggest factors affecting the development of exports are exchange rates and inflation.

The infrastructure problems are still an important problem, not only in Indonesia but also in other countries (Prasetyo \& Firdaus, 2009) and this shows that road infrastructure can influence on economic growth.

High poverty results in a decrease in the rate of economic growth. According to Yolanda (2017), poverty can endanger the bargaining position of a country in world relations, and the future of the nation and country is bleak, therefore the problem of poverty must be a concern. Factor causing high poverty rate according to Yolanda (2017), Farhad, KK, Arab and Naz, Hafeez-urRehman (2011 is inflation.

Unemployment is a complex problem faced by the most countries in the world, both developed and developing countries. The problem is that it leads to the economic and social problems, so that the level of unemployment that occurs can result in a decline in the rate of economic growth. This is of course because of the level of unemployment and economic growth theoretically has a negative relationship.

\section{References}

Akeju, K. F., \& Olanipekun, D. B. (2014). Unemployment and economic growth in Nigeria. Journal of Economics and Sustainable Development, 5(4), 138-144.

Ali, H., \& Jabeen, A. (2015). Effects of education on economic growth: Evidence from Pakistan. American Journal of Economics, Finance and Management, 1(6), 579-585.

Arsyad, L. (2005). Pengantar Perencanaan Pembangunan Ekonomi Daerah. Edisi Kedua. Penerbit BPFE-UGM. Yogyakarta.

Aurangzeb, A., \& Haq, U. (2012). Impact of investment activities on economic growth of Pakistan. Business and Management review, 2(1), 92-100.

Barro, R. J. (2003). Determinants of economic growth in a panel of countries. Annals of economics and finance, 4, 231-274.

Berg, H. V. (2005). Economic Growth and Development. United States: McGraw-Hill Irwin.

Chang, C. C., \& Mendy, M. (2012). Economic growth and openness in Africa: What is the empirical relationship?. Applied Economics Letters, 19(18), 1903-1907.

Chidoko, C., \& Sachirarwe, I. (2015). An analysis of the Impact of investment on economic growth in Zimbabwe. Review of Knowledge Economy, 2(2), 93-98.

Haifa, M., \& Mabrouka B. (2016). Higher education, Graduate unemployment, Poverty and Economic growth in Tunisia, 19902013, Atlantic Review of Economics - 1st Volume.

Hanif, N., \& Arshed, N. (2016). Relationship between school education and economic growth: SAARC countries. International Journal of Economics and Financial Issues, 6(1), 294-300.

Jhingan, ML. (2013). Ekonomi Pembangunan dan Perencanaan. Penerbit PT Raja Graindo ; Jakarta.

Kalsum, U.(2017). Pengaruh Pengangguran dan Inflasi terhadap Pertumbuhan Ekonomi di Sumatera Utara. Jurnal Ekonomikawan, 17(1), 87-94.

Kashi, F. K., \& Tash, M. N. S. (2014). Effects of macroeconomic variables on poverty in Iran (Application of bootstrap technique). Theoretical and Applied Economics, 21(5), 594. 
Kobzev Kotásková, S., Procházka, P., Smutka, L., Maitah, M., Kuzmenko, E., Kopecká, M., \& Hönig, V. (2018). The impact of education on economic growth: The case of India. Acta Universitatis Agriculturae Et Silviculturae Mendelianae Brunensis, $66(1), 253-262$.

Kodoatie, R. J. (2005). Pengantar Menejemen Infrastruktur, Jogjakarta: Pustaka Pelajar.

Kukaj, D. (2018). Impact of unemployment on economic growth: Evidence from Western Balkans. European Journal of Marketing and Economics, 1(1), 10-18.

Leasiwal, T. C. (2013). The Analysis of Indonesia Economic Growth: a Study in Six Big Islands in Indonesia. Journal of Economics, Business, \& Accountancy Ventura, 16(1).

Lloyd, P. J., \& MacLaren, D. (2002). Measures of trade openness using CGE analysis. Journal of Policy Modeling, $24(1), 67-81$.

Makaringe, S. C., \& Khobai, H. (2018). The effect of unemployment on economic growth in South Africa (1994-2016). MPRA Paper No 85305.

Manamba, E. \& Massawe, J. (2016). Investment and economic growth: An empirical analysis for Tanzania. Turkish Economic Review, 3(4). 579-609.

Mankiw, N.G. (2010), Makro Ekonomi, Edisi Keenam, Penerbit Erlangga, Jakarta.

Maryaningsih, N., Hermansyah, O., \& Savitri, M. (2014). The Role of Infrastructure on Economic Growth in Indonesia. Bulletin of Monetary, Economics and Banking, 17(1), 55-88.

Mohseni, M., \& Jouzaryan, F. (2016). Examining the effects of inflation and unemployment on economic growth in Iran (19962012). Procedia Economics and Finance, 36, 381-389.

Moteff, J., Copeland, C., \& Fischer, J. (2003, January). Critical infrastructures: What makes an infrastructure critical?. Library of Congress Washington DC Congressional Research Service.

Ndulu, B., Kritzinger-van, N., \& Reinikka. (2005). Infrastructure, Regional Integration and Growth in Sub-Saharan Africa. The National, Regional and International Challenges Fondad, 101-121.

Naz, A., Chaudhry, H. U. R., Hussain, M., Daraz, U., \& Khan, W. (2012). Inflation: The Social Monster Socio-Economic and Psychological Impacts of Inflation and Price Hike on Poor Families of District Malakand, Khyber Pakhtunkhwa, Pakistan. International Journal of Business and Social Science, 2(14).

Ng, C. P., Law, T. H., Jakarni, F. M., \& Kulanthayan, S. (2019, April). Road infrastructure development and economic growth. In IOP Conference Series: Materials Science and Engineering (Vol. 512, No. 1, p. 012045). IOP Publishing.

Nowbutsing, B. M. (2014). The impact of openness on economic growth: Case of Indian Ocean rim countries. Journal of Economics and Development Studies, 2(2), 407-427.

NSS, R. L. P., Suryawardana, E., \& Triyani, D. (2015). Analisis dampak pembangunan infrastruktur jalan terhadap pertumbuhan usaha ekonomi rakyat di Kota Semarang. Jurnal Dinamika Sosial Budaya, 17(1), 82-103.

Odit, M. P., Dookhan, K., \& Fauzel, S. (2010). The impact of education on economic growth: The case of Mauritius. International Business \& Economics Research Journal (IBER), 9(8).

Sheng, B., Fatima, S., Irshad, M. S., \& Ramzan, M. (2019). Impact of Openness on Economic Growth in Developing Economies: An Empirical Analysis. European Online Journal of Natural and Social Sciences, 8(3), pp-411.

Sukirno, S. (2000). Makroekonomi Modern. Jakarta: PT Raja Drafindo Persada.

Sucipto, B., Hailuddin, H., \& Harsono, I. (2018). Analysis of Economic Growth Determination and Invesment Needs in North Lombok. Quantitative Economics Research, 1(1), 25-31.

Sjafrizal. (2012). Ekonomi Wilayah dan Perkotaan. Rajawali Pers. Jakarta

Thirlwall, A.P. (2006). Growth and Development with Special Reference to Developing Economies. $8^{\text {th }}$ Ed. United Kingdom: Palgrave Macmillan.

Todaro, M.P., \& Smith, S.C. (2006). Pembangunan Ekonomi. Jilid I Edisi Kesembilan. Haris Munandar (penerjemah). Erlangga, Jakarta.

Yolanda. (2017). Impacts of export development on unemployment in Indonesia. European Research Studies Journal, 20(3A), $758-773$.

Yolanda. (2017). Analysis of factors affecting inflation and its impact on human development index and poverty in Indonesia. European Research Studies Journal, 20(4B), 38 - 56.

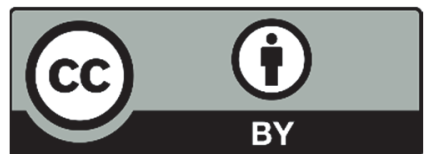

(C) 2021 by the authors; licensee Growing Science, Canada. This is an open access article distributed under the terms and conditions of the Creative Commons Attribution (CC-BY) license (http://creativecommons.org/licenses/by/4.0/). 